\title{
Clinical Trials of a New Antitumor Polypeptide: Neocarzinostatin (NCS)
}

\author{
Mitsuo Takahashi \\ Yonezawa City Hospital, Yonezawa \\ Kazuyoshi Toriyama, Hiroshi Maeda, Mikio Kikuchi, \\ Katsuo Kumagai and Nakao Ishida \\ Department of Bacteriology (Prof. N. Ishida), \\ Tohoku University School of Medicine, Sendai
}

\begin{abstract}
Neocarzinostatin, a new polypeptide which had shown antitumor activity in animals, was given to 17 patients with advanced malignant tumors. Five of 17 patients showed objective regression of tumors and disappearance of clinical symptoms. On account of the limited clinical experiences, no assertion can be made as to the range of therapeutic indication or to the comparison of neocarzinostatin with other antitumor substances. These preliminary observations, however, justify further extensive therapeutic trials.
\end{abstract}

Neocarzinostatin (NCS) is an antitumor polypeptide isolated from the culture beer of Streptomyces carcinostaticus var. F-41. ${ }^{3}$ Its chemical characterization ${ }^{4,5}$, ${ }^{8-10}$ and mode of action ${ }^{6,11,12}$ have been reported previously by our group. NCS was subjected to extensive preclinical investigation and was shown to have a marked effect on a number of transplantable rodent tumors, ${ }^{12,7,13}$ The present report describes the results of preliminary clinical trials in 17 patients with malignant neoplasms.

\section{Methods}

Neocarzinostatin (NCS) was supplied in ampoule containing $2 \mathrm{mg}$ of dry substance prepared at the Kayakn Antibiotic Research Laboratory (Tokyo). The drug was kept in dry-ice-box for storage and transportation. It was readily soluble in isotonic saline or $20 \%$ glucose solution. The dose of NCS given to most patients was $2 \mathrm{mg}$ per day per person by intravenous injection for 10 to 17 days, and this treatment was repeated at appropriate intervals for one or two weeks.

The present report is concerned with the results obtained from 17 adult patients with malignant tumors hospitalized in the Yonezawa City Hospital and treated with NCS.

\section{RESULTS}

\section{Patients}

The data of the patients who received NCS are summarized in Tables 1 and 2. Eleven of the 17 patients treated with NCS had various malignant tumors in the

Received for publication, April 8, 1969. 
TaBLe 1. Patient and clinical diagnosis

\begin{tabular}{|c|c|c|c|}
\hline $\begin{array}{l}\text { Case } \\
\text { No. }\end{array}$ & $\begin{array}{l}\text { Patient } \\
\text { Sex }\end{array}$ & Age & Diagnosis \\
\hline 1 & K.S. q & 71 & Carcinoma of the oesophagus \\
\hline 2 & Y.S.Q & 62 & Carcinoma of the ovarium \\
\hline 3 & T.T. \& & 74 & Carcinoma of the rectum \\
\hline 4 & K.S. & 57 & Carcinoma of the stomach \\
\hline 5 & F.S. 8 & 39 & Carcinoma of the stomach \\
\hline 6 & N.K.P & 39 & Oesophagocardial carcinoma \\
\hline 7 & F.S. 3 & 50 & Carcinoma of the rectum \\
\hline 8 & R.I. $\delta$ & 45 & Carcinoma of the lung \\
\hline 9 & K.S. 今 & 48 & Carcinoma of the panereas \\
\hline 10 & C.S. \& & 61 & Carcinoma of the stomach \\
\hline 11 & D.H. $\delta$ & 68 & Carcinoma of the stomach \\
\hline 11 & K.Y.? & 70 & Carcinoma of the urine bladder \\
\hline 13 & T.T. 8 & 71 & Carcinoma of the tongue \\
\hline 14 & M.F. $\delta$ & 19 & Myosarcoma in the peritoneal cavity \\
\hline 15 & H.S. $\delta$ & 68 & Carcinoma in the pelvic bone \\
\hline 16 & F.S. $甲$ & 38 & $\begin{array}{l}\text { Carcinoma of the liver (probable metastasis of } \\
\text { the carcinoma of the rectum) }\end{array}$ \\
\hline 17 & I.Y. 8 & 31 & Acute myeloid leukemia \\
\hline
\end{tabular}

digestive organs (Table 1). Two patients, Cases 6 and 15, received $100 \mathrm{mg}$ of NCS or more in three series of therapy (Table 2).

\section{Toxicity}

Local phlebitic reaction was not seen in any of the cases. Nausea and vomiting after the drug injection were seen in none of the cases.

A slight fever from 37 to $38^{\circ} \mathrm{C}$ was seen in 3 cases (Cases 9, 12 and 13) during the treatment, but the temperature in all cases fell to the normal range in the course of the treatment (Table 3). In a patient (Case 11), cutaneous flushing on the face associated with wheezing hyperpnea and chest pain was observed immediately after the intravenous injection on the third day of the second course of NCS-therapy (Table 3). This patient was completely relieved of the sufferings within 30 minutes.

Three patients (Cases 1, 6 and 15), who received NCS for a long term, showed a decline in leukocyte counts, but it was not so severe as to make it necessary to discontinue the treatment.

No patient showed a decline in erythrocyte counts, hematocrit and thrombocytes. There was no apparent change in serum protein, electrolytes, bilirubin, alkaline phosphatase, thymol turbidity or transaminase.

\section{Antitumor effects}

Seven (Cases 3, 4, 6, 13, 15, 16 and 17) of 17 patients treated with NCS showed objective improvement of the diseases (Table 4). Five of the seven were considered to have definitely responded to NCS-therapy. These five cases (Cases $3,4,13,15$ and 16) are described below to illustrate the clinical effects of NCStherapy. 
TABLE 2. Schedule of therapy

\begin{tabular}{|c|c|c|c|c|}
\hline \multirow{2}{*}{ Case No. } & \multirow{2}{*}{$\begin{array}{r}\text { Previous } \\
\text { therapy }\end{array}$} & \multicolumn{2}{|c|}{ Therapy } & \multirow[b]{2}{*}{ Total (mg) } \\
\hline & & $\begin{array}{c}\text { Number of } \\
\text { courses }\end{array}$ & mg $\times$ times & \\
\hline 1 & - & $\begin{array}{l}1 \\
2\end{array}$ & $\begin{array}{l}2 \times 10 \\
4 \times 15\end{array}$ & $\begin{array}{l}20 \\
60\end{array}$ \\
\hline 2 & MM-C & 1 & $2 \times 3$ & 6 \\
\hline 3 & - & 1 & $2 \times 10$ & 20 \\
\hline 4 & MM-C & 1 & $2 \times 10$ & 20 \\
\hline 5 & MM-C,5Fu & 1 & $2 \times 10$ & 20 \\
\hline \multirow[t]{3}{*}{6} & MM-C & 1 & $2 \times 4$ & 8 \\
\hline & & 2 & $2 \times 31$ & 62 \\
\hline & & 3 & $2 \times 15$ & 30 \\
\hline 7 & $\mathrm{MM} \cdot \mathrm{C}, \mathrm{EX}$ & 1 & $2 \times 10$ & 20 \\
\hline 8 & EX,MM-C & 1 & $2 \times 15$ & 30 \\
\hline \multirow[t]{2}{*}{9} & - & 1 & $2 \times 5$ & 10 \\
\hline & & 2 & $2 \times 10$ & 20 \\
\hline \multirow[t]{2}{*}{10} & $\rightarrow$ & 1 & $2 \times 14$ & 28 \\
\hline & & 2 & $2 \times 3$ & 6 \\
\hline 11 & - & 1 & $2 \times 17$ & 34 \\
\hline \multirow[t]{2}{*}{12} & - & 1 & $2 \times 10$ & 20 \\
\hline & - & 2 & $2 \times 10$ & 20 \\
\hline 13 & & 1 & $2 \times 10$ & 20 \\
\hline 14 & - & 1 & $2 \times 14$ & 28 \\
\hline \multirow[t]{3}{*}{15} & $\mathbf{E X}, \mathbf{x}$-ray & 1 & $2 \times 10$ & 20 \\
\hline & & 2 & $2 \times 31$ & 62 \\
\hline & & 3 & $2 \times 16$ & 32 \\
\hline \multirow[t]{2}{*}{16} & - & 1 & $2 \times 15$ & 30 \\
\hline & & 2 & $2 \times 12$ & 24 \\
\hline 17 & - & 1 & $2 \times 41^{*}$ & 82 \\
\hline
\end{tabular}

MM-C: Mitomycin C 5FU: 5-Fluorouracil EX: Endoxan

* Combination with 6-mercapto-purine and predonisolone

TABLE 3. Toxicity of NCS

\begin{tabular}{|c|c|c|c|c|c|}
\hline $\begin{array}{l}\text { Case } \\
\text { No. }\end{array}$ & $\begin{array}{c}\text { Local } \\
\text { inflammatory } \\
\text { reaction }\end{array}$ & $\begin{array}{l}\text { Nausea or } \\
\text { vomiting }\end{array}$ & Fever & $\begin{array}{l}\text { Leukocyte } \\
\text { count }\end{array}$ & Others \\
\hline 1 & - & - & - & $6,900-2,600$ & 一 \\
\hline 1 & - & - & - & - & 一 \\
\hline 3 & - & - & - & - & - \\
\hline 4 & - & - & - & - & - \\
\hline 5 & - & - & - & - & - \\
\hline 6 & - & - & - & $4,800-2,200$ & - \\
\hline 7 & - & - & - & - & - \\
\hline 8 & - & - & - & - & - \\
\hline 9 & - & - & + & - & - \\
\hline 10 & - & 一 & - & - & 一 \\
\hline 11 & - & 一 & - & - & $+\uparrow$ \\
\hline 12 & - & - & + & - & $\cdots$ \\
\hline 13 & - & - & + & $\cdots$ & - \\
\hline 14 & - & - & - & - & $\ldots$ \\
\hline 15 & - & - & 一 & $8,800-3,300$ & - \\
\hline 16 & - & - & - & - & - \\
\hline 17 & - & $-\cdots$ & - & $t^{*}$ & - \\
\hline
\end{tabular}

* Leukemic cells $†$ Allergic symptoms 
TABLE 4. Antitumor effect of NCS-objective improvement

\begin{tabular}{|c|l|}
\hline Case No. & \multicolumn{1}{|c}{ Effect } \\
\hline 1 & None \\
2 & None \\
3 & Decrease in size of the rectum tumor \\
4 & Decrease in size of the stomach tumor \\
5 & None \\
6 & Inhibition of the tumor growth of the stomach \\
7 & None \\
8 & None \\
9 & None \\
10 & None \\
11 & None \\
13 & None \\
14 & Decreasse in size of lymph nodes \\
15 & None \\
16 & Decrease in size of liver tumor \\
17 & Decrease in size of the pelvic bone tumor \\
& Decrease in size of the spleen and liver, Fall \\
& of fever
\end{tabular}

Case 3. Carcinoma of the rectum. The patient was a 74-year-old woman. The diagnosis of adenocarcinoma of the rectum was made by romanoscopy and exfoliative cytology in February, 1968. The patient had mucinous diarrhea with blood, marked pain of the lower abdomen, and a severe loss of body weight. A total amount of $20 \mathrm{mg}$ of NCS was administered. The details are given in Table 2 . Progressive improvement in the clinical symptoms occurred, and within 2 weeks her complaint disappeared. Half a month after the termination of treatment, a romanoscopic examination revealed marked reduction of the tumor in the rectum. Now, eight months after the beginning of therapy, she has no clinical symptoms and leads healthy life, although she has still a large tumor of the rectum with scattered foci of cicatrization.

Case 4. Carcinoma of the stomach. A 57-year-old man, first examined at the Hospital in December 1967, complained of chronic anorexia, chest pain like intercostal neuralgia and loss of body weight. Roentgenogram of the stomach and gastroscope-camera examination revealed a round-shape tumor of about $7 \mathrm{~cm}$ in diameter with necrotic surface at the angle of the stomach. Cytological examination of gastric washings showed malignant cells. The chest roentgenogram revealed a lesion in the field of middle thoracic vertobrae indicative of a metastasis. He was initially treated with mitomycin C (MM) for 6 days in January 1968. At the sixth administration of the drug (MM), he complained of severe hematemesis without any improvement, of the disease, so that the treatment was discontinued. Two months after the termination of the MM therapy (March, 1968), the patient received NCS injection. Within a few days, the chest pain completely disappeared, and 2 weeks later he was relieved from anorexia, nausea, vomiting or signs of gastric bleeding. Roentogenogram and gastrocamera examinations in May 1968 proved that gastric tumor masses had markedly decreased in size, although they had 
not completely disappeared. In September 1968, the patient received a surgical operation for subtotal resection of the stomach. The surgical operation proved again that the tumor had been reduced to a small nodule of $1.5 \mathrm{~cm}$ in diameter, and the histological examination of the nodule revealed adenocarcinoma.

Case 13. Carcinoma of the tongue. The patient was a 71-year-old man who had received a radical operation of carcinoma of the tongue in November 1967 at the Hospital. He again visited the Hospital in May 1968. Then he complained of difficulty in swallowing, pharyngeal pain and marked swelling of submaxillar lymph nodes. His clinical history and biopsy of the submaxillar nodes proved metastatic carcinoma. NCS was administered, as shown in detail in Table 2. There was a gradual decrease of the tumor masses of the lymph nodes and improvement of swallowing, but definite evidence of regrowth of the neck tumors was abserved one month after the initial therapy. The patient failed to respond to the second course of NCS administration. Death was due to progressive cancer.

Case 15. Carcinoma in the pelvic bone. The patient was a 68 -year-old man, and the diagnosis of metastatic carcinoma was made by biopsy of the tumor in the pelvic bone in December 1967, although a primary focus was not ascertained. In January 1968, he complained of difficulties in his gait which caused severe ischias-like pain. He was initially treated with localized radiotherapy and endoxan without any improvement. The patient received the first course of NCS therapy in March 1968. A marked decrease in the size of nodular lesions in the pelvis was observed by roentogenogram after the course. There was gradual relief of pelvic pain and improvement in the gait. The patient received a second course of therapy with two weeks' interval after the first course of NCS treatment. One month after the termination of the second course of NCS therapy, he did not complain of any pain and he was able to walk. However, recurrence of the lesion in the pelvis occurred and the patient failed to respond to the third course of NCStherapy.

Case 16. Cancer of the liver and colon. A 38-year-old woman first visited the Hospital in January 1968. She complained of mucous bloody stool, meteorism and enlargement of the liver to 6 finger width. Because of anorexia and severe loss of body weight she could not walk unsupported. The patient received two courses of NCS treatment (Table 2). After the first course, enlargement of the liver decreased from 6 to 3 finger width. Pains in the abdomen and bloody stool ceased to occur and her appetite surprisingly improved, resulting in a marked increase of body weight. Two weeks after termination of the first course of treatment, regrowth of liver tumor and development of jaundice were noticed and the second course of therapy was started. Jaundice completely disappeared and improvement in physical activity was observed in two days after the termination of the second course, but other objective signs did not regress so far. The patient died three months after the therapy. 
Therapeutic results of the other two cases are as follows: Case No. 6, under the diagnosis of esophagocardial carcinoma, received three courses of NCS treatment in total and the patient was alive 6 months after beginning of the NCS-therapy. In this case, the disappearance of difficulties in swallowing, vomiting and epigastral pain were seen, whenever the NCS-treatment was started and the tumor growth in the stomach was inhibited during the observation period, although the decrease of the tumor size was not observed by means of either roentgenography or gastrocamera.

In Case 17 of acute myeloid leukemia, the patient received NCS in combination with 6-mercaptopurine (6MP). After the administration of $45 \mathrm{mg}$ NCS and $4,000 \mathrm{mg}$ of $6 \mathrm{MP}$, splenomegaly and pathologic white cells in the peripheral blood completely disappeared. However, the effect of NCS therapy could not be evaluated, on account of the combination therapy.

Besides the 7 cases described above, subjective improvement of general conditions was noted in the rest and some physical examinations indicated transient improvement in Cases 1 and 12 (Table 5), whereas no objective improvement was observed.

TABLE 5. Antitumor effect of NCS-subjective improvement

\begin{tabular}{r|l}
\hline Case No. & \multicolumn{1}{|c}{ (transiently or consistently) } \\
\hline 1 & Improvement of difficulties in swallowing \\
2 & None \\
3 & Disappearance of abdominal pain \& bloody stool \\
4 & Disappearance of chest pain \& vomiting \\
5 & None \\
6 & Disappearance of vomiting \& abdominal pain \\
7 & None \\
8 & None \\
9 & None \\
10 & None \\
11 & None \\
12 & Disappearance of hematuria \\
13 & Disappearance of pharyngeal pain \& difficulties in swallowing \\
14 & None \\
15 & Disappearance of lumbago, improvement in the gait \\
16 & Disappearance of abdominal pain and bloody stool \\
17 & Improvement in physical activity
\end{tabular}

\section{DISCUSSION}

The cases reported here are the first ones for the clinical evaluation of NCS, a new antitumor antibotic. It was shown that NCS brought about considerable improvement of clinical symptoms of patients with malignant tumors and inhibited active tumor growth in several cases, whereas the toxic side effects of the drug in a therapeutic dose were not severe. A toxic side effect was collapselike symptom which appeared when the NCS therapy was resumed, although it was only transiently observed in one of 42 cases including the patients who are now receiving repeated NCS therapy in the hospital. 
Much more patients have to be tested with NCS before a definite evaluation of this new antibiotic can be made in comparison with the known chemotherapeutic agents. At the present time, clinical evaluation of NCS is being carried out in greater detail with approximately one hundred patients at five different institutions with a broader spectrum of tumors.

The observation that NCS was effective to tumors resistant to other chemotherapeutics or radiation suggests the absence of cross resistance at least to some other drugs and $x$-ray. This assumption is in agreement with the observation by Bradner $^{2}$ that no cross resistance to NCS was seen in sublines of L1210 resistant to one or more well-known antitumor antimetabolites.

Although Case 17 was excluded from the clinical evaluation of NCS-therapy owing to simultaneous administration of other drugs (Table 2), the marked improvement in this case suggests the combination effect with $6 \mathrm{MP}$ and NCS in human leukemia. Such an effect is also expected from the existence of collateral sensitivity to NCS in sublines of L1210 resistant to $6 \mathrm{MP}$ and the combination effect of the two drugs in L1210 in mice. ${ }^{2}$

At present, limited experience with NCS does not permit an evaluation of the effect of NCS against hopatoma. A phase III study for hepatomas or metastatic tumors of the liver is now scheduled in Japan.

TABLE 6. Summary

\begin{tabular}{|c|c|c|c|}
\hline Case No. & $\begin{array}{c}\text { Diagnosis of patients } \\
\text { showed objective } \\
\text { improvement }\end{array}$ & $\begin{array}{l}\text { Observation period } \\
\text { from the beginning of } \\
\text { NCS-therapy (days) }\end{array}$ & Remarks \\
\hline 1 & & 60 & Died \\
\hline 2 & & 40 & Died \\
\hline 3 & $\begin{array}{l}\text { Carcinoma of the } \\
\text { rectum }\end{array}$ & 210 & Alive \\
\hline 4 & $\begin{array}{l}\text { Carcinoma of the } \\
\text { stomach }\end{array}$ & 205 & Alive \\
\hline 5 & & 82 & Died \\
\hline 6 & $\begin{array}{l}\text { Oesophagocardial } \\
\text { carcinoma }\end{array}$ & 182 & Alive \\
\hline 7 & & 130 & Died \\
\hline 8 & & 37 & Died \\
\hline 9 & & 20 & Died \\
\hline 10 & & 83 & Died \\
\hline 11 & & 102 & Died \\
\hline 12 & & 35 & Died \\
\hline 13 & $\begin{array}{l}\text { Carcinoma of the } \\
\text { tongue }\end{array}$ & 59 & Died \\
\hline 14 & & 26 & Died \\
\hline 15 & $\begin{array}{l}\text { Carcinoma of the } \\
\text { pelvic bone }\end{array}$ & 97 & Died \\
\hline 16 & Hepatoma & 117 & Died \\
\hline 17 & $\begin{array}{l}\text { Acute myelocytic } \\
\text { leukemia }\end{array}$ & 145 & Alive \\
\hline
\end{tabular}




\section{References}

1) Bradner, W.T. \& Hutchison, D.J. Neocarzinostatin (NSC-69856): An antitumor antibiotic effective against ascitic leukemia L 1210 in mice. Cancer Chemoth. Rep., $1966,50,79-84$.

2) Bradner, W.T. \& Rossomano, C.A. Therapy of leukemia L-1210 with the antibotic neocarzinostatin in combination with standard drugs. Proc. Amer. Ass. Cancer Res., 1968, 9, 8.

3) Ishida, N., Miyazaki, K., Kumagai, K. \& Rikimaru, M. Neocarzinostatin, an antitumor antibiotic of high molecular weight; Isolation, physicochemical properties and biological activities. J. Antibiot. (Tokyo), 1965, 18, 68-76.

4) Kitame, S., Maeda, H., Kumagai, K., \& Ishida, N. Tryptic digestion of an antitumor protein: Neocarzinostatin. J. Antibiot. (Tokyo), 1968, 21, 460-462.

5) Kumagai, K., Maeda, H. \& Ishida, N. Biological activity of neocarzinostatin and its derivatives. Antimicrobiol. Agents and Chemotherapy, 1966., 1967, pp. 546-550.

6) Kumagai, K., Ono, Y., Nishikawa, T. \& Ishida, N. Cytological studies on the effect of neocarzinostatin on HeLa cells. J. Antibiot. (Tokyo), 1966, 19, 69-74.

7) Kumagai, K. Antitumor activity of carzinostatin. J. Antibiot. (Tokyo), 1962, 15, 5359 .

8) Maeda, H., Kumagai, K. \& Ishida, N. Characterization of neocarzinostatin. J. Antibiot. (Tokyo) 1966, 19, 253-259.

9) Maeda, H., Koyanagi, T. \& Ishida, N. C-terminal amino acid of neocarzinostatin. Biochim. biophys. Acta, 1968, 160, 249-251.

10) Maeda, H., \& Ishida, N. Conformational study of antitumor proteins: Neocarzinostatin and a deaminated derivative. Biochim. biophys. Acta, 1967, 147, 597-599.

11) Ono, Y., Watanabe, Y. \& Ishida, N. Mode of astion of neocarzinostatin: Inhibition of DNA synthesis and degradation of DNA in Sarcina lutea. Biochim. biophys. Acta, 1966, 119, 46-58.

12) Ono, Y., Ito, Y., Maeda, H. \& Ishida, N. Mode of action of neocarzinostatin: Requirement of protein synthesis for neocarzinostatin-mediated DNA degradation in Sarcina lutea. Biochim. biophys. Acta, 1968, 155, 616-618.

13) Sato, H., Ichimura, H., Kumagai, K. \& Ishida, N. Antitumor activity of neocarzinostatin on aseites tumor in rats. Proceedings of the Japanese Cancer Association, the 27th Annual Meeting, 1968, Tokyo, Japan. 